\title{
Konsep Ekonomi Pada Masa Khalifah
}

\author{
Rezki Amalia Fathurrahman (90100118108) \\ Email:rezkiamalia56@gmail.com
}

\begin{abstract}
Abstrak
Sepeninggal Rasulullah para sahabat melanjutkan perjuangan Rasulullah dalam membuat kebijakan ekonomi. Khalifah yang pertama membuat kebijakan yaitu Abu Bakar Shiddiq yang dimana ada permasalahan yang muncul pada awal kepemimpinan dimana kaum muslim secara perlahan-lahan tidak mau lagi membayar zakat lagi karena Abu Bakar Shiddiq memerintahkan kepada pasukan untuk memerangi orang yang enggan membayar zakat terutama orang murtad yang biasa disebut dengan Perang Ridddah yaitu perang melawan orang-orang yang murtad atau keluar dari agama Islam. Beliau juga meneruskan perjuangan Rasulullah dengan membuat Baitul Maal yang berfungsi sebagai pendistribusian harta kepada yang berhak menerimanya. Khalifah kedua, Umar Bin Khattab melakukan berbagai inovasi dalam perekonomian misalnya Umar Bin Khattab membuat kebijakan pertanian, membuat diwan atau pengawas pasar, membuat kebijakan baru, membuat mata uang sendiri, mengedepankan keadilan dalam berbagai aspek terutama dalam perekonomian dan pemerintah. Khalifah ketiga, Usman Bin Affan berhasil melakukan menaklukkan di berbagai daerah, menanda tangani empat kontrak dagang pada daerah-daerah taklukkan yang kemudian melakukan tindakan cepat dalam rangka pengembangan sumber daya alam. Selain itu Usman mebangun infrstruktur, membentuk kekuatan militer seperti Angkatan Laut, tidak menerima upah selama menjabat sebagai khalifah, menggunakan zakat untuk di bagikan kepada Masyarakat yang membutuhkan tetapi ada sisi terburuk dari beliau yaitu kebijakan cendrung berpihak kepada keluarga atau kerabat yang dimana menimbulkan kekecewaan bagi masyarakat muslim sehingga terjadi konflik hingga berakhirnya terbunuh Usman oleh seseorang tidak dikenal. Khalifah terakhir yaitu Ali Bin Abi Thalib yang dikenal sederhana sehingga ia rela menarik diri dari pendaftar penerima Baitul Maal, melakukan penegakkan hukum dan tidak membeda-bedakan semua adil, mengedepankan pemerataan, menetapkan pajak kebun dan zakat terhadap sayuran.
\end{abstract}

Kata Kunci: Konsep Ekonomi pada Masa Abu Bakar As-Shiddiq, masa Umar Bin Khattab, masa Usman Bin Affan, masa Ali bin Abi Thalib, perang Riddah 


\section{Pendahuluan}

Setelah Rasulullah wafat para sahabat meneruskan perjuangan beliau. Khalifah pertama yaitu Abu Bakar As-Shidiq diawal kepemimpinan menemui permasalahan pada saat ingin melakukan pengumpulan zakat dimana orang-orang enggan lagi membayar zakat.(P3EI UII Bekerja sama dengan BI 2019). Di tambah lagi banyak di antara para muslim mulai murtad, munculnya nabi palsu sehingga para sahabat memutuskan untuk memerangi kelompok orang murtad yang disebut dengan Perang Riddah.(Mudhiiah 2015). Maka dari itu beliau membangun lagi Baitul Maal yang berfungsi untuk mendistribusikan harta dan melanjutkan sebagaimana Rasulullah lakukan. Dan beliau menggaji para aparat negara.(P3EI UII Bekerja sama dengan BI 2019).

Khalifah kedua, Umar Bin Khattab pada masanya beliau melakukan berbagai kebijakan yang beliau mendirikan Baitul Maal dan melakukan peluasan atau membuka cabang di berbagai daerah taklukkan. Selain itu Baitul Maal ini juga berfungsi sebagai pelaksana membuat kebijakan fiskal, membayar pajak tanah atau yang disebut dengan Kharaj, selain itu beliau juga memanfaat sektor petanian bagi perekonomian negara. Khalifah ketiga Usman Bin Affan, beliau berhasil menaklukkan beberapa daerah seperti Balk, Kabul, Ghazni, Kernan dan Sistan, menanda tangani empat kontrak dagang untuk pengembangan sumber daya alam dan membentuk armada laut yang ada di Laut Mediterania dibawah pimpina Muawiyah. Khalifah terakhir Ali Bin Abi Thalib yang dimana beliau dikenal sederhana sehingga beliau menarik diri dari penerima bantuan Baitul Maal sebesar 
5000 dirham, beliau melakukan pemerataan pendapatan rakyat, melakukan strategi pada administrasi umum.(Mudhiiah 2015)

\section{Pembahasan}

Khalifah pertama, Abu Bakar As-Shidiq, dimasa beliau memimpin menemui berbagai permasalahan dimana muncul beberapa orang yang tidak mau membayar zakat dan orang-orang mulai murtad sehingga terjadi Perang Riddah atau perang melawan orang murtad. Sehingga beliau memutuskan membangun Baitul Maal yang berfungsi mendistribusikan harta kepada rakyat meneruskan perjuangan Rasulullah. Selain itu beliau membuat sistem penggajian kepada Aparat Negara misalnya untuk khalifah saja hanya membayar sekitar 2,5 dan 2,75 dirham setiap hari tetapi tunjangan ini tidak cukup sehingga di tetapkan 2000 atau 2500 dirham jadi pembayarannya untuk gaji sekitar 6000 dirham per tahun.(P3EI UII Bekerja sama dengan BI 2019). Setelah beliau melakukan menyelesaikan permasalahan dalam negeri beliau langsung melakukan ekspansi di bagian wilayah utara dalam menghadapi melawan Romawi dan Persia yang selalu mengancam bagi umat Islam.(Wahab 2019)

Khalifah Kedua, Umar Bin Khattab pada masa kepemimpinannya beliau melakukan inovasi pada perekonomian. Misalnya di sektor pertanian melakukan berbagai langkah yang dimana beliau menghadiahkan masyarakat sebuah lahan bagi siapa yang bisa mengarapnya untuk dikelola jika siapa saja gagal mengelola sebuah lahan pertanian maka kepemilikan atas tanah tersebut akan di cabut. Lalu 
beliau membangun saluran irigasi di daerah taklukkannya. Dan dibangun sebuah waduk, tangka, kanal air dan pintu-pintu air serbaguna untuk kelancaran pendistribusian air. Selain itu melakukan penyempurnaan perekonomian yang sehat dengan mengurangi beban pajak pada sebesar $50 \%$ untuk pajak perdagangan nabati dan kurma. Membangun pasar-pasar di daerah taklukkan dan membuat acara pecan dagang Ukaz di Hijaz. Membangun Baitul Maal secara permanen yang kemudian membuka cabang dan di ibukota provinsi dan membentuk diwan atau semacam pengawas pasar dan membuat komite nassab atau mengetahui garis keturunan keluarga yang tujuannya untuk membuat laporan sensus penduduk yang ada di Madinah(P3EI UII Bekerja sama dengan BI 2019). Selain itu beliau membuat kebijakan zakat pada pendistribusian zakat misalnya bagaimana cara muzakki menyalurkan zakat ini kepada mustahik yang dapat di klasifikasikan atas dua yang pertama amwal bathinah yaitu harta yang terdiri dari emas, perak maupun sejenisnya dimana harta ini memberikan keleluasan kepada muzakki untuk di salurkan kepada musthahik. Kedua, amwal zhahirah yang terdiri dari barang dagang, peternakan, pertanian, madu ataupun sejenisnya yang dimana jenis harta ini biasanya ditarik oleh negara lalu di bagikan kepada masyarakat.(Aqbar, Khaerul dan Iskandar 2019)

Khalifah ketiga, Usman Bin Affan. Pada masa kepemimpinan beliau pada tahun enam pertama sudah banyak negara berhasil di taklukkan seperti Balkan, Kabul , Ghazni, Kerman dan Sistan. Setelah negara-negara tersebut di taklukkan beliau menanda tangani empat kontrak dagang daerah taklukkan untuk mengembangkan sumber daya alam di daerah tersebut. Misalnya aliran air di gali, 
jalan dibangun, pohon dan buah-buahan ditanam dan membentuk badan kepolisian tetap untuk menjaga jalur perdagangan. Selain itu membentuk armada laut kaum Muslimin yang di pimpin oleh Muawiyah hingga berhasil membangun kekuatan di wilayah laut Mediterania. Selain itu beliau mengambil kebijakan untuk tidak menggambil upah negara pada saat jadi khalifah bahkan upah beliau di simpan di bendahara negara. Kebijakan Usman dalam perekonomian adalah memberikan bantuan dan santunan kepada masyarakat, membayar zakat sesuai dengan porsi masing-masing hal ini dilakukan untuk mencegah penyelewangan zakat dari oknum pengelola zakat. Dan selama kepemimpinan tidak ada yang terlalu signifikan karena kebijakan beliau ini menguntungkan bagi keluarga Usman sehingga muncul kekecewaan kaum muslimin sehingga terjadi konflik hingga tiba saat beliau di bunuh oleh seseorang yang tidak dikenal. Khalifah terakhir yaitu Ali Bin Abi Thalib yang dikenal khalifah sangat sederhana bahkan rela menarik diri dari pendaftar bantuan Baitul Maal sebesar 5000 dirham setiap tahun. Selain itu beliau sangat jeli dan ketat dalam hal keuangan. Pada masa pemerintahannya beliau melakukan pemeratan pendapatan sehingga semuanya sama tidak membeda-bedakan yang lain. Menetapkan pajak hutan sebesar 4000 dirham dan meminta izin kepada Gubernur Kufah Ibnu Abbas untuk memungut pajak tersebut juga memungut zakat sayuran. Salah kelebihan beliau adalah membuat strategi masalah administrasi umum dan masalah tersebut tersusun rapi hingga menunjuk Malik Ashter bin Harits untuk mendekripsikan pembagian tugas kepada pejabat tinggi dan staf-stafnya memberikan upah sesuai kinerjanya.(Kharidatul Mudhiiah 2015) 


\section{Kesimpulan}

Bisa disimpulkan bahwa masing-masing khalifah memiliki kelebihan. Misalnya Abu Bakar As-Shiddiq dimasa beliau memimpin menemui berbagai permasalahan dimana muncul beberapa orang yang tidak mau membayar zakat dan orang-orang mulai murtad sehingga terjadi Perang Riddah atau perang melawan orang murtad. Sehingga beliau memutuskan membangun Baitul Maal yang berfungsi mendistribusikan harta kepada rakyat meneruskan perjuangan Rasulullah. Umar Bin Khattab di masa kepemimpinan beliau melakukan inovasi pada perekonomian. Misalnya di sektor pertanian melakukan berbagai langkah yang dimana beliau menghadiahkan masyarakat sebuah lahan bagi siapa yang bisa mengarapnya untuk dikelola jika siapa saja gagal mengelola sebuah lahan pertanian maka kepemilikan atas tanah tersebut akan di cabut. Lalu beliau membangun saluran irigasi di daerah taklukkannya. Dan dibangun sebuah waduk, tangka, kanal air dan pintu-pintu air serbaguna untuk kelancaran pendistribusian air. Selain itu melakukan penyempurnaan perekonomian yang sehat dengan mengurangi beban pajak pada sebesar 50\% untuk pajak perdagangan nabati dan kurma. Khalifah ketiga, Usman Bin Affan. Pada masa kepemimpinan beliau pada tahun enam pertama sudah banyak negara berhasil di taklukkan seperti Balkan, Kabul , Ghazni, Kerman dan Sistan. Setelah negara-negara tersebut di taklukkan beliau menanda tangani empat kontrak dagang daerah taklukkan untuk mengembangkan sumber daya alam di daerah tersebut. Misalnya aliran air di gali, jalan dibangun, pohon dan buah-buahan ditanam dan membentuk badan kepolisian tetap untuk menjaga jalur perdagangan. Selain itu membentuk armada laut kaum Muslimin yang di pimpin 
oleh Muawiyah hingga berhasil membangun kekuatan di wilayah laut Mediterania. Khalifah terakhir yaitu Ali Bin Abi Thalib yang dikenal khalifah sangat sederhana bahkan rela menarik diri dari pendaftar bantuan Baitul Maal sebesar 5000 dirham setiap tahun. Selain itu beliau sangat jeli dan ketat dalam hal keuangan. 


\section{Daftar Pustaka}

Aqbar, Khaerul dan Iskandar, Azwar. 2019. "Kontekstualisasi Ekonomi Zakat Dalam Mengentaskan Kemiskinan Studi Kebijakan Zakat Umar Bin Khattab Dan Perzakatan Di Indonesia." Laa Maisyir 6(2):226-245.

Kharidatul Mudhiiah. 2015. "Analisis Sejarah Pemikiran Ekonomi Islam Masa Klasik.” Iqthishadia 8(2):189-210.

P3EI UII Bekerja sama dengan BI. 2019. Ekonomi Islam. Jakarta: Rajawali Pers.

Wahab, Abdul. 2019. “ALOKASI BELANJA NEGARA (Studi Komparasi Era Rasulullah Dan Khulafaurrasyidin Dengan Era Pemerintahan Joko Widodo Periode 2014-2019).” Jurnal Studi Keislaman 5(2):2614-1124. 